Revista Brasileira de Farmacognosia Brazilian Journal of Pharmacognosy 22(4): 854-860, Jul./Aug. 2012

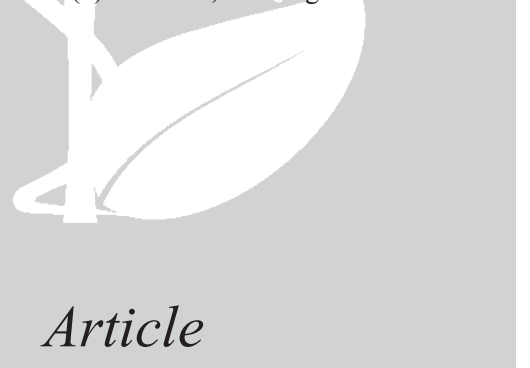

Received 28 Nov 2011

Accepted 12 Jan 2012

Available online 21 Jun 2012

Keywords:

seaweeds

fatty acids

extraction and transesterification methods

ISSN 0102-695X

http://dx.doi.org/10.1590/S0102-

695X2012005000088

\section{Comparison of extraction and transesterification methods on the determination of the fatty acid contents of three Brazilian seaweed species}

\author{
Aline P. Martins, ${ }^{1}$ Nair S. Yokoya,${ }^{2}$ Pio Colepicolo ${ }^{* 1}$ \\ ${ }^{I}$ Departamento de Bioquímica, Instituto de Química, Universidade de São \\ Paulo, Brazil, \\ ${ }^{2}$ Núcleo de Pesquisa em Ficologia, Instituto de Botânica, Secretaria de Estado \\ do Meio Ambiente, São Paulo, Brazil.
}

\begin{abstract}
Seaweeds are photosynthetic organisms important to their ecosystem and constitute a source of compounds with several different applications in the pharmaceutical, cosmetic and biotechnology industries, such as triacylglycerols, which can be converted to fatty acid methyl esters that make up biodiesel, an alternative source of fuel applied in economic important areas. This study evaluates the fatty acid profiles and concentrations of three Brazilian seaweed species, Hypnea musciformis (Wulfen) J.V. Lamouroux (Rhodophya), Sargassum cymosum C. Agardh (Heterokontophyta), and Ulva lactuca L. (Chlorophyta), comparing three extraction methods (Bligh \& Dyer - B\&D; AOAC Official Methods - AOM; and extraction with methanol and ultrasound - EMU) and two transesterification methods $\left(7 \% \mathrm{BF}_{3}\right.$ in methanol $-\mathrm{BF}_{3}$; and $5 \% \mathrm{HCl}$ in methanol - $\left.\mathrm{HCl}\right)$. The fatty acid contents of the three species of seaweeds were significantly different when extracted and transesterified by the different methods. Moreover, the best method for one species was not the same for the other species. The best extraction and transesterification methods for H. musciformis, S. cymosum and U. lactuca were, respectively, $\mathrm{AOM}-\mathrm{HCl}, \mathrm{B} \& \mathrm{D}-\mathrm{BF}_{3}$ and $\mathrm{B} \& \mathrm{D}-\mathrm{BF}_{3} / \mathrm{B} \& \mathrm{D}-\mathrm{HCl}$. These results point to a matrix effect and the method used for the analysis of the fatty acid content of different organisms should be selected carefully.
\end{abstract}

\section{Introduction}

Seaweeds are photosynthetic organisms important to their ecosystem since they release $\mathrm{O}_{2}$ into seawater and contribute to carbon fixation and nutrient cycling. In addition, they provide food and shelter for many animals. These organisms constitute a source of compounds with several different applications that can be used in the food, pharmaceutical and biotechnology industries (Gressler et a., 2009; 2011; Cardozo et al., 2007; 2008).

Among the compounds synthesized by macroalgae, fatty acids are highlighted because of their importance to human health (Cardozo et al., 2007). Thus, omega-3 (n-3) and omega-6 (n-6) are essential nutrient precursors of a group of eicosanoids that regulate developmental and regulatory physiology. Furthermore, triacylglycerols can be converted to the fatty acid methyl esters present in biodiesel (Chisti, 2007).

Biodiesel is an alternative source of fuel produced from plant and animal oils (Marchetti et al.,
2007) and the use of algae for its production is of great interest due to their high photosynthetic rate compared to terrestrial plants and the possibility of cultivation in different conditions and in marine waters (Aresta et al., 2005), avoiding the use of arable land.

During the production of biodiesel, two steps are necessary: i. extraction of triacylglycerols from the raw material; and ii. transesterification to produces fatty acid methyl esters (FAME) (Chisti, 2007). Lipids can be extracted using solvent extraction or other techniques such as supercritical fluid extraction and microwave extraction. For the synthesis of FAME, acidic or basic catalysis, as well as other methods, can be used (Carrapiso \& Garcia, 2000). Kumari et al. (2011) tested the extraction methods of Bligh \& Dyer (1959), Folch (1957) and Cequier-Sánchez (2008) in three species of macroalgae and noted that the macroalgal matrix, the extraction method, and the buffer all influenced the content of fatty acid recovered, which shows that the method used should be selected with caution.

In Brazil, a country with a coastline of over $7000 \mathrm{~km}$, the main raw material for biodiesel production 
is soybean oil (80\%), followed by bovine fat (10\%). There is little information on the fatty acid composition of Brazilian species of marine benthic algae. This knowledge is very relevant, since the profile of fatty acids of raw materials influence biodiesel properties such as the cetane number, iodine value, cold filter plugging point, and oxidation stability (Ramos et al., 2009).

Considering the importance of a knowledge of the fatty acid composition of Brazilian seaweeds, as well as the choice of extraction and transesterification methods to be used, this study evaluates the fatty acid profile of three Brazilian seaweed species, comparing three methods of triacylglycerol extraction and two methods of transesterification to produces FAME.

\section{Materials and Methods}

\section{Algal material}

The study was conducted with Hypnea musciformis (Wulfen) J.V. Lamouroux (Rhodophya), Sargassum cymosum C. Agardh (Heterokontophyta) and Ulva lactuca L. (Chlorophyta), collected from the intertidal zone in Ubatuba, São Paulo State, Brazil. The specimens were cleaned by removing the epiphytic organisms and washing with seawater. Subsequently samples were frozen under liquid $\mathrm{N}_{2}$, lyophilized, ground to a powder with liquid nitrogen and stored at $-80{ }^{\circ} \mathrm{C}$ in the dark. All analyses were performed with three replicates. Voucher specimens were deposited in the SP herbarium under the numbers SP 427377 (Hypnea musciformis), SP 427378 (Sargassum cymosum), and SP 427379 (Ulva lactuca).

\section{Total lipid extraction}

Three different methods for lipid extraction were tested:

1. Bligh \& Dyer (1959) (B\&D): the macerated lyophilized algae $(0.33 \mathrm{~g}$ dry mass) was suspended in PBS and $125 \mu \mathrm{L}$ of the $\mathrm{C} 13: 0$ triacylglyceride standard (C13) solution ( $5 \mathrm{mg} \mathrm{mL}^{-1}$ in hexane) and $12.5 \mathrm{ml}$ of chloroform:methanol:water $(2: 2: 1)$ were added. The mixture was centrifuged and the chloroform phase was transferred to another flask and dried under $\mathrm{N}_{2}(\mathrm{~g})$.

2. AOAC Official Methods (2001) (AOM): to the macerated lyophilized algae ( $1 \mathrm{~g}$ dry mass) was added $0.5 \mathrm{~mL}$ of the C13:0 triacylglyceride standard solution ( $5 \mathrm{mg} \mathrm{mL}^{-1}$ in hexane), $50 \mathrm{mg}$ pyrogallic acid and $1 \mathrm{~mL}$ of ethanol. This material was suspended in $5 \mathrm{~mL}$ of $8.3 \mathrm{M} \mathrm{HCl}$, mixed and maintained in a shaker at $80{ }^{\circ} \mathrm{C}$ for $40 \mathrm{~min}$. After cooling, the samples were extracted with ethyl ether $(12 \mathrm{~mL})$ and petroleum ether $(12 \mathrm{~mL})$. The sample was centrifuged and the ether phase was transferred to another flask and dried under $\mathrm{N}_{2}(\mathrm{~g})$.

3. Extraction with methanol and ultrasound (EMU): the macerated lyophilized algae (0.5 g dry mass) was suspended in $5 \mathrm{~mL}$ of methanol and then 125 $\mu \mathrm{L}$ of the triacylglyceride C13:0 standard solution (5 mg $\mathrm{mL}^{-1}$ in hexane) was added. The sample was submitted to ultrasound for $15 \mathrm{~min}$ and then dried under $\mathrm{N}_{2}(\mathrm{~g})$.

\section{Fatty acid transesterification}

Two different methods for fatty acid transesterification were tested:

1. $\mathrm{BF}_{3}$ in methanol $\left(\mathrm{BF}_{3}\right)$ : the dry lipid extracts obtained by the B\&D and AOM methods were dissolved in $1 \mathrm{~mL}$ of $\mathrm{BF}_{3}(7 \%$ in methanol $)$ and $0.5 \mathrm{~mL}$ of toluene and heated to $100{ }^{\circ} \mathrm{C}$ for $45 \mathrm{~min}$. After the reaction, 2.5 $\mathrm{mL}$ of water was added at room temperature and the FAME extracted with $1 \mathrm{~mL}$ of hexane.

2. $\mathrm{HCl}$ in methanol $(\mathrm{HCl})$ : to the dry lipid extracts obtained by the B\&D, AOM and EMU methods were added $500 \mu \mathrm{L}$ of $5 \% \mathrm{HCl}$ in methanol and the mixture was incubated for $2 \mathrm{~h}$ at $100{ }^{\circ} \mathrm{C}$. After the reaction, $1.25 \mathrm{~mL}$ of water was added at room temperature and the FAME extracted with $1.25 \mathrm{~mL}$ of hexane.

\section{Chromatographic analysis}

The FAME were analyzed by gas chromatography coupled with mass spectrometry (QP2010, Shimadzu, Kyoto, Japan) with a $30 \mathrm{~m}$ fused silica capillary column (HP-5MS with $0.25 \mu \mathrm{m}$ film, Agilent). A sample $(1 \mu \mathrm{L})$ was injected at temperature of $220^{\circ} \mathrm{C}$ and with split of $1: 10$. Helium was used as the carrier gas at a flow rate of

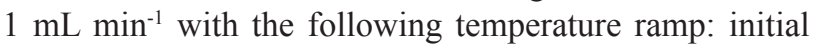
temperature of $60{ }^{\circ} \mathrm{C}$ with an increase of $5{ }^{\circ} \mathrm{C}$ per min up to $260^{\circ} \mathrm{C}$, which was maintained for $10 \mathrm{~min}$. The reference used for FAMEs was the standard Supelco 37 Component FAME Mix.

\section{Quantification}

Quantification of each fatty acid methyl ester (FAME) was based on the standard curve made with Supelco 37 Component FAME Mix. C13 recovery was calculated as $\left[(\mathrm{Cf} \bullet 100) \cdot \mathrm{Ci}^{-1}\right]$, where $\mathrm{Cf}$ is the final concentration obtained from the standard curve and $\mathrm{Ci}$ is the $\mathrm{C} 13$ concentration added to the sample.

\section{Data analysis}

Data were subjected to analysis of variance (ANOVA) of one factor, followed by the comparison test of Student-Newman-Keuls, considering a confidence level of $95 \%$. 


\section{Results}

Comparison of extraction and transesterification methods

There was significant difference in the $\mathrm{C} 13$ recovery between the different methods tested only for Sargassum cymosum, and it was higher in the B\&D$\mathrm{BF}_{3}$ method. There was no significant difference in the recovery of $\mathrm{C} 13$ among species (Figure 1).

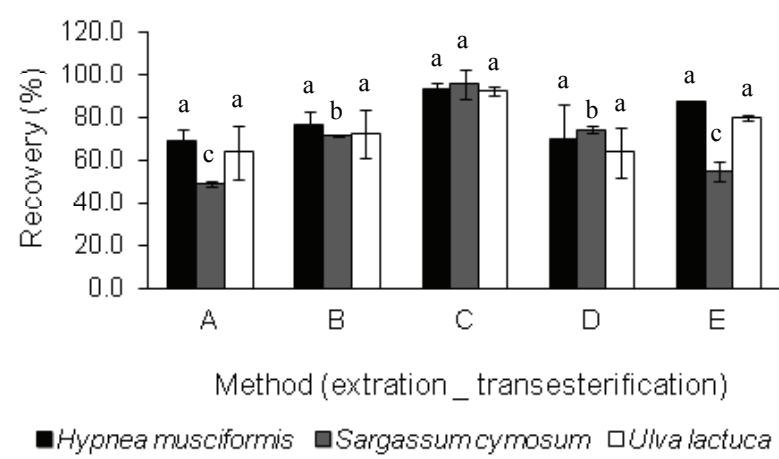

Figure 1. Recovery of the C13:0 triacylglyceride internal standard in extraction and transesterification by the different methods with Hypnea musciformis, Sargassum cymosum and Ulva lactuca collected from Ubatuba, São Paulo, Brazil. The extraction transesterification methods are: A. EMU-HCl; B. $\mathrm{B} \& \mathrm{D}-\mathrm{HCl}$; C. B\&D-BF ${ }_{3}$; D. AOM-HCl; E. AOM-BF . Each $_{3}$ data point is the mean of three replicates and the bars are the standard deviation For each species, distinct letters indicate significant differences between the methods tested according to one-way ANOVA and to the comparison test of StudentNewman-Keuls $(p<0.05)$.

H. musciformis showed a higher saturated fatty acid content in the $\mathrm{AOM}-\mathrm{BF}_{3}$ and $\mathrm{AOM}-\mathrm{HCl}$ methods (Table $1 \mathrm{~A}$ ), which is a consequence of the highest concentrations of palmitic and myristic acid methyl esters when extracted and transesterified by these methods (Figure $2 \mathrm{~A}$ and B). The contents of monounsaturated fatty acid and of palmitoleic acid methyl ester also were higher in the AOM-HCl method (Table $1 \mathrm{~A}$ and Figure $2 \mathrm{~B}$ ), while the content of oleic acid methyl ester was higher in the $\mathrm{B} \& \mathrm{D}-\mathrm{BF}_{3}$, $\mathrm{AOM}-\mathrm{HCl}$ and $\mathrm{AOM}-\mathrm{BF}_{3}$ methods (Figure $2 \mathrm{~B}$ ). The contents of polyunsaturated fatty acid, represented by arachidonic acid methyl ester, and of total fatty acid were higher in the $\mathrm{AOM}-\mathrm{HCl}$, and $\mathrm{AOM}-\mathrm{BF}_{3}$ methods (Table $1 \mathrm{~A}$ and Figure $2 \mathrm{~B}$ ).

S. cymosum showed higher contents of saturated fatty acid and of myristic and palmitic acid methyl esters in the $\mathrm{B} \& \mathrm{D}-\mathrm{BF}_{3}$ method (Table $1 \mathrm{~B}$ and Figure 3 $\mathrm{A}$ and $\mathrm{B})$. The contents of monounsaturated fatty acid and of oleic acid methyl ester were also higher in the
$\mathrm{B} \& \mathrm{D}-\mathrm{BF}_{3}$ method (Table $1 \mathrm{~B}$ and Figure $3 \mathrm{~B}$ ), while the content of palmitoleic acid methyl ester was higher in the $\mathrm{B} \& \mathrm{D}-\mathrm{BF}_{3}$ and $\mathrm{B} \& \mathrm{D}-\mathrm{HCl}$ methods (Figure $3 \mathrm{~B}$ ). The contents of polyunsaturated and total fatty acid and of aracdonic and linoleic acid methyl esters were higher in the $\mathrm{B} \& \mathrm{D}-\mathrm{BF}_{3}$ method (Table $1 \mathrm{~B}$ and Figure $3 \mathrm{~B}$ ).
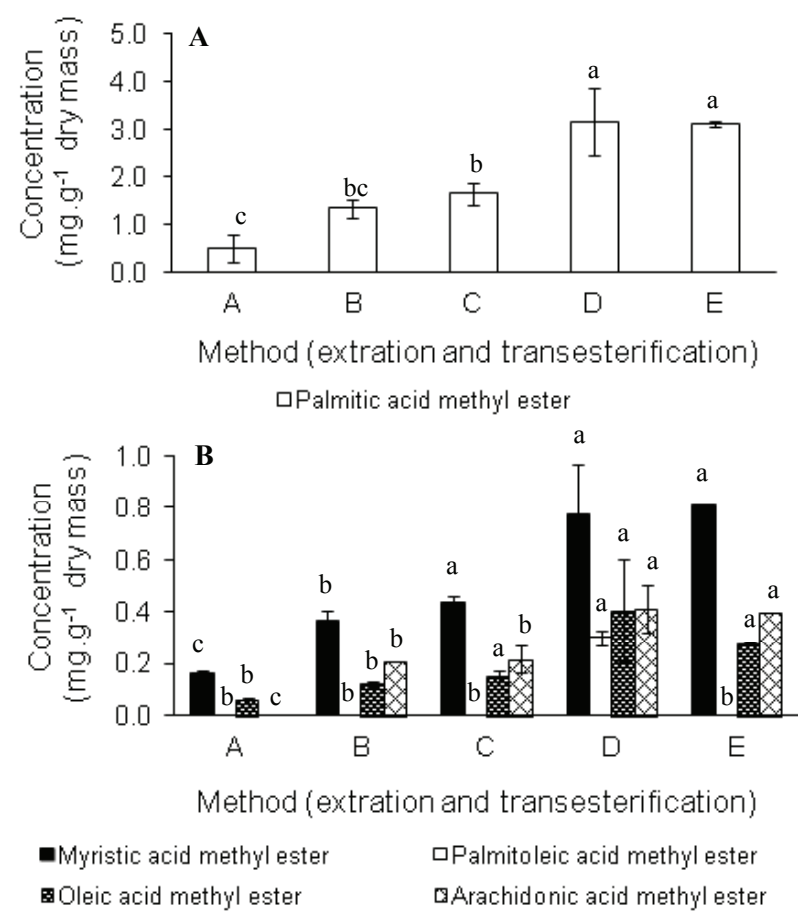

Figure 2. Fatty acid methyl ester concentrations ( $\mathrm{mg} \mathrm{g}^{-1}$ dry weight) of Hypnea musciformis collected from Ubatuba, São Paulo, Brazil. The extraction- transesterification methods are: A. EMU-HCl; B. B\&D-HCl; C. B\&D-BF ; D. AOM-HCl; E. $\mathrm{AOM}-\mathrm{BF}_{3}$. Each data point is the mean of three replicates and the bars are the standard deviation. For each fatty acid, distinct letters indicate significant differences between the methods tested according to one-way ANOVA and to the comparison test of Student-Newman-Keuls $(p<0.05)$.

There was no significant difference in saturated fatty acid and palmitic acid methyl ester contents among the different methods tested for $U$. lactuca (Table 1 $\mathrm{C}$ and Figure $4 \mathrm{~A}$ ). The same was observed for the monounsaturated fatty acid and oleic acid methyl ester (Table $1 \mathrm{C}$ and Figure $4 \mathrm{~B}$ ). However, the content of palmitoleic acid methyl ester was higher when extracted with the $\mathrm{B} \& \mathrm{D}-\mathrm{BF}_{3}$ and $\mathrm{B} \& \mathrm{D}-\mathrm{HCl}$ methods (Figure $4 \mathrm{~B}$ ). The content of polyunsaturated acid was higher in the $\mathrm{B} \& \mathrm{D}-\mathrm{BF}_{3}, \mathrm{~B} \& \mathrm{D}-\mathrm{HCl}$ and AOM-HCl methods (Table $1 \mathrm{C}$ ). The content of linoleic acid methyl ester was higher when extracted with the $\mathrm{B} \& \mathrm{D}-\mathrm{BF}_{3}$ and $\mathrm{B} \& \mathrm{D}-\mathrm{HCl}$ methods and the content of linolenic acid methyl ester was lower when extracted with the AOM- $\mathrm{BF}_{3}$ method (Figure 4 B). 
Table 1. Fatty acid concentrations ( $\mathrm{mg} \mathrm{g}^{-1}$ dry weight) obtained by different extraction and transesterification methods for Hypnea musciformis (A), Sargassum cymosum (B) and Ulva lactuca (C) collected from Ubatuba, São Paulo, Brazil.

\begin{tabular}{ccccccc}
\hline & Fatty acid & EMU & B\&D-HCl & B\&D-BF & AOM-HCl & $A_{3}$ \\
A & Saturated & $0.69 \pm 0.36^{\mathrm{b}}$ & $1.71 \pm 0.16^{\mathrm{b}}$ & $1.63 \pm 0.44^{\mathrm{b}}$ & $3.93 \pm 0.73^{\mathrm{a}}$ & $3.94 \pm 0.05^{\mathrm{a}}$ \\
& Monounsaturated & $0.06 \pm 0.01^{\mathrm{b}}$ & $0.12 \pm 0.01^{\mathrm{b}}$ & $0.15 \pm 0.02^{\mathrm{b}}$ & $0.80 \pm 0.09^{\mathrm{a}}$ & $0.28 \pm 0.01^{\mathrm{b}}$ \\
& Polyunsaturated & n.d. & $0.21 \pm 0.01^{\mathrm{b}}$ & $0.22 \pm 0.04^{\mathrm{b}}$ & $0.41 \pm 0.08^{\mathrm{a}}$ & $0.40 \pm 0.01^{\mathrm{a}}$ \\
& Total & $0.72 \pm 0.38^{\mathrm{b}}$ & $2.04 \pm 0.37^{\mathrm{b}}$ & $2.08 \pm 0.27^{\mathrm{b}}$ & $4.95 \pm 1.02^{\mathrm{a}}$ & $4.62 \pm 0.06^{\mathrm{a}}$ \\
& Saturated & $0.82 \pm 0.27^{\mathrm{c}}$ & $2.32 \pm 1.00^{\mathrm{bc}}$ & $3.85 \pm 0.24^{\mathrm{a}}$ & $2.30 \pm 0.17^{\mathrm{b}}$ & $1.50 \pm 0.37^{\mathrm{bc}}$ \\
& Monounsaturated & $0.20 \pm 0.10^{\mathrm{c}}$ & $0.87 \pm 0.18^{\mathrm{b}}$ & $1.19 \pm 0.06^{\mathrm{a}}$ & $0.61 \pm 0.05^{\mathrm{b}}$ & $0.33 \pm 0.15^{\mathrm{c}}$ \\
& Polyunsaturated & n.d..$^{\mathrm{d}}$ & $0.61 \pm 0.10^{\mathrm{b}}$ & $0.83 \pm 0.03^{\mathrm{a}}$ & $0.42 \pm 0.02^{\mathrm{c}}$ & $0.11 \pm 0.08^{\mathrm{d}}$ \\
& Total & $1.01 \pm 0.37^{\mathrm{d}}$ & $3.80 \pm 1.26^{\mathrm{b}}$ & $5.87 \pm 0.32^{\mathrm{a}}$ & $3.33 \pm 0.24^{\mathrm{bc}}$ & $1.94 \pm 0.59^{\mathrm{cd}}$ \\
& Saturated & $1.85 \pm 0.42^{\mathrm{a}}$ & $2.13 \pm 0.45^{\mathrm{a}}$ & $2.49 \pm 0.19^{\mathrm{a}}$ & $2.01 \pm 0.31^{\mathrm{a}}$ & $2.28 \pm 0.51^{\mathrm{a}}$ \\
& Monounsaturated & $0.52 \pm 0.11^{\mathrm{a}}$ & $0.72 \pm 0.15^{\mathrm{a}}$ & $0.79 \pm 0.01^{\mathrm{a}}$ & $0.52 \pm 0.08^{\mathrm{a}}$ & $0.46 \pm 0.07^{\mathrm{a}}$ \\
& Polyunsaturated & $0.68 \pm 0.15^{\mathrm{b}}$ & $0.91 \pm 0.12^{\mathrm{ab}}$ & $1.09 \pm 0.01^{\mathrm{a}}$ & $0.83 \pm 0.09^{\mathrm{ab}}$ & $0.27 \pm 0.03^{\mathrm{c}}$ \\
& Total & $3.05 \pm 0.68^{\mathrm{a}}$ & $3.76 \pm 0.71^{\mathrm{a}}$ & $4.37 \pm 0.19^{\mathrm{a}}$ & $3.36 \pm 0.47^{\mathrm{a}}$ & $3.02 \pm 0.61^{\mathrm{a}}$ \\
\hline
\end{tabular}

Each value is the mean $\pm \mathrm{SD}$ of three replicates. For each fatty acid (saturated, monounsaturated, polyunsaturated and total) distinct letters indicate significant differences between the different methods tested according to the one-way ANOVA and to the comparison test of Student-Newman-Keuls $(p<0.05)$.
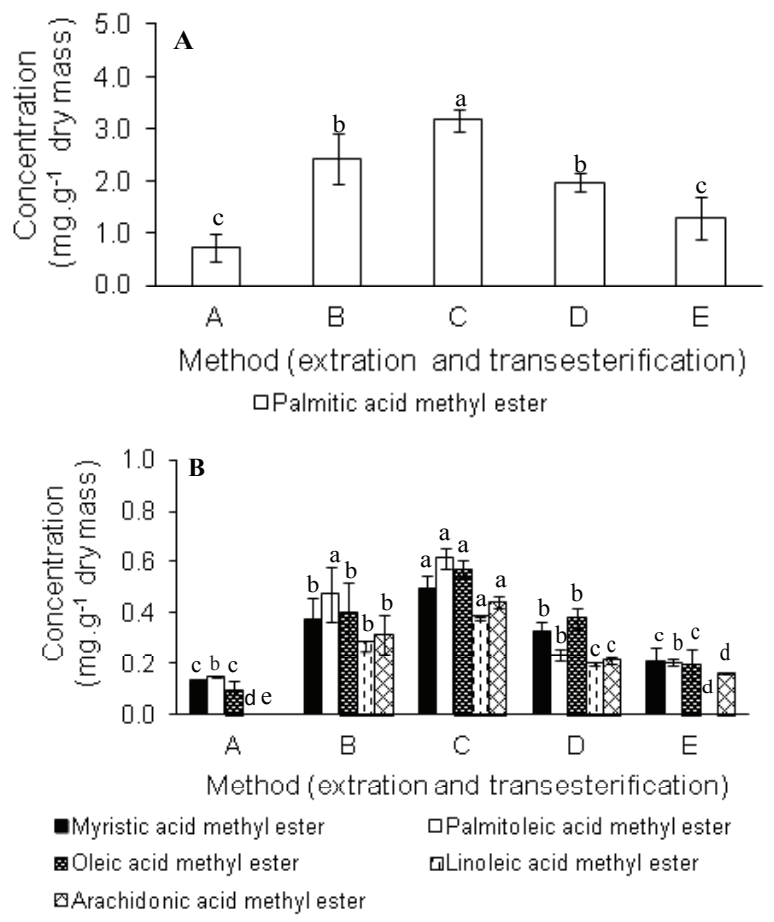

Figure 3. Fatty acid methyl ester concentrations ( $\mathrm{mg} \mathrm{g}^{-1}$ dry weight) of Sargassum cymosum collected from Ubatuba, São Paulo, Brazil. The extraction- transesterification methods are: A. EMU-HCl; B. B\&D-HCl; C. B\&D-BF ; D. AOM-HCl; E. $\mathrm{AOM}-\mathrm{BF}_{3}$. Each data point is the mean of three replicates and the bars are the standard deviation. For each fatty acid, distinct letters indicate significant differences between the methods tested according to one-way ANOVA and to the comparison test of Student-Newman-Keuls $(p<0.05)$.
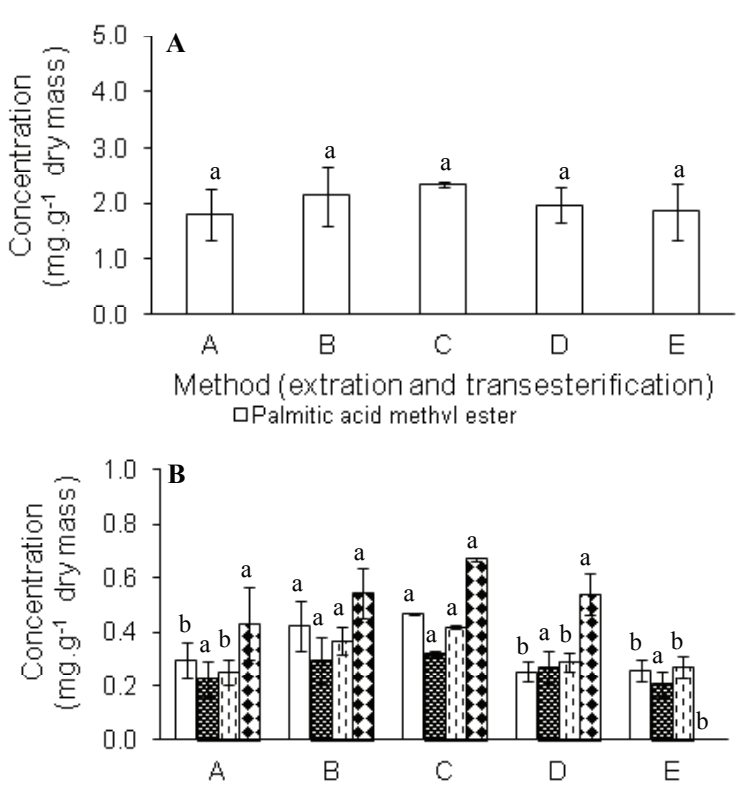

Method (extration and transesterification)

口Palmitoleic acid methyl ester ooleic acid methyl ester

口Linoleic acid methyl ester DLinolenic acid methyl ester

Figure 4. Fatty acid methyl ester concentrations ( $\mathrm{mg} \mathrm{g}^{-1}$ dry weight) of Ulva lactuca collected from Ubatuba, São Paulo, Brazil. The extraction- transesterification methods are: A. EMU-HCl; B. B\&D-HCl; C. B\&D-BF ; D. AOM-HCl; E. $\mathrm{AOM}-\mathrm{BF}_{3}$. Each data point is the mean of three replicates and the bars are the standard deviation. For each fatty acid, distinct letters indicate significant differences between the methods tested according to one-way ANOVA and to the comparison test of Student-Newman-Keuls $(p<0.05)$. 
Comparison between the species studied

The comparison between the species studied was made by choosing two extraction methods. For Hypnea musciformis, the best extraction method, which yielded the highest value of saturated, unsaturated and polyunsaturated fatty acids, was the AOM-HCl method. For Sargassum cymosum it was $\mathrm{B} \& \mathrm{D}-\mathrm{BF}_{3}$ and for Ulva lactuca the $\mathrm{B} \& \mathrm{D}-\mathrm{BF}_{3}$ and $\mathrm{B} \& \mathrm{D}-\mathrm{HCl}$ methods. Thus, comparison of the fatty acid profile of these species was made considering the $\mathrm{AOM}-\mathrm{HCl}$ and $\mathrm{B} \& \mathrm{D}-\mathrm{BF}$ methods.

In both methods tested, the three species showed higher concentrations of saturated fatty acids and palmitic acid was the major fatty acid (Figure $5 \mathrm{~A}$ and $\mathrm{B}$ ). However, when comparing species, and when the extraction and transesterification were made using the B\&D-BF ${ }_{3}$ method, S. cymosum and H. musciformis showed the highest and lowest contents of this fatty acid, respectively. S. cymosum also showed higher concentrations of palmitoleic, oleic and arachidonic acid methyl esters when the $\mathrm{B} \& \mathrm{D}-\mathrm{BF}_{3}$ method was used (Figure $5 \mathrm{~A}$ ).
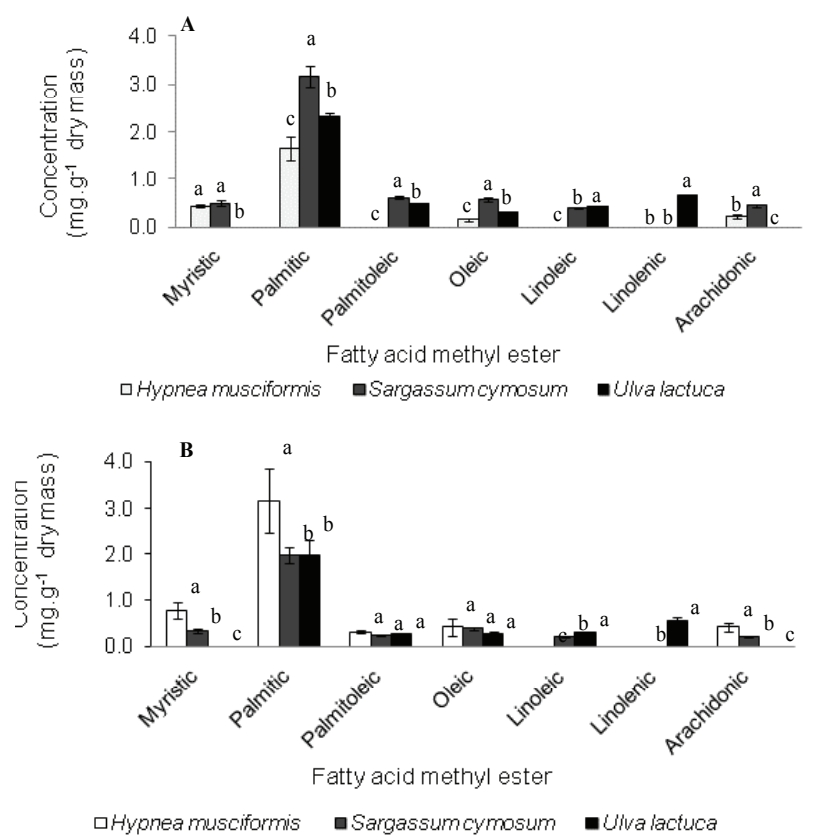

Figure 5. Fatty acid methyl ester concentrations ( $\mathrm{mg} \mathrm{g}^{-1}$ dry weight) of Hypnea musciformis, Sargassum cymosum and Ulva lactuca collected from Ubatuba, São Paulo, Brazil. A. $\mathrm{B} \& \mathrm{D}-\mathrm{BF}_{3}$ method; B. AOM-HCl method. Each data point is the mean of three replicates and the bars are the standard deviation. For each fatty acid, distinct letters indicate significant differences between species according to one-way ANOVA and to the comparison test of Student-NewmanKeuls $(p<0.05)$.
However, when the AOM-HCl method was used, H. musciformis showed higher concentrations of palmitic, myristic and arachidonic acid methyl esters than the other species and significant differences between the species for palmitoleic and oleic acid methyl esters were not observed (Figure 5 B). Moreover, this species did not yield palmitoleic acid methyl ester when $\mathrm{B} \& \mathrm{D}-\mathrm{BF}_{3}$ method was used (Figure $5 \mathrm{~A})$ and linoleic and linolenic acid methyl esters were not detected, independent of the method used.

Ulva lactuca was the only species in which linolenic acid methyl ester was detected.

\section{Discussion}

The present study showed significant differences in the observed fatty acid contents of three species of seaweeds, Hypnea musciformis, Sargassum cymosum and Ulva lactuca, when extracted and transesterified by different methods. Moreover, the best method for one species was not necessarily the best for the other species. The best extraction and transesterification methods for $H$. musciformis, S. cymosum and U. lactuca were, respectively, $\mathrm{AOM}-\mathrm{HCl}, \mathrm{B} \& \mathrm{D}-\mathrm{BF}_{3}$ and $\mathrm{B} \& \mathrm{D}-\mathrm{BF}_{3} / \mathrm{B} \& \mathrm{D}-\mathrm{HCl}$. Similar results were observed by Kumari et al. (2011), where the content of total lipids and fatty acids of Ulva fasciata Delile, Gracilaria corticata (J. Agardh) J. Agardh and Sargassum tenerrimum J. Agardh varied with the extraction method tested and the best method differed for each species. These results may be due to the matrix effect, since these species differ in their content of carbohydrates and proteins, which can interact with triacylglycerides.

When comparing the fatty acid contents of the three species of seaweed studied using the AOM-HCl method, $H$. musciformis showed higher concentrations of palmitic, myristic and arachidonic acid methyl esters than the other species. Significant differences between the species for palmitoleic and oleic acid methyl esters were not observed. The same was not the case for the $\mathrm{B} \& \mathrm{D}-\mathrm{BF}_{3}$ method. These results highlight the matrix effect and show that different results are generated as a consequence of the method used, which can produce false results. If only the results generated by the AOM-HCl method were considered, H. musciformis would be the species that produces more palmitic acid methyl ester. However, if only the $\mathrm{B} \& \mathrm{D}-\mathrm{BF}_{3}$ method were considered, $S$. cymosum would be the species that produces more of this fatty acid. Thus, care must be taken in studies that compare the content of fatty acids from different algal species since differences in the results can be due to the matrix effect rather than to differences in intrinsic concentrations in the sample.

The three species studied showed higher concentrations of saturated fatty acids, and palmitic acid was the major fatty acid, which is in agreement 
with the findings for other red algae (Guaratini et al., 2007; Gressler et al., 2010; Gressler et al., 2011), green algae (Ortiz et al., 2006; Yaich et al., 2011) and brown algae (Khotimchenko, 1991; Noviendri et al., 2011).

$S$. cymosum had a higher content of monounsaturated than polyunsaturated fatty acids. Similar results were found for Ochtodes secundiramea (Montagne) M.A. Howe (Gressler et al., 2011) and $U$. lactuca (Yaich et al., 2011). However, the opposite was observed for $U$. lactuca (present study) and for species of red algae such as Plocamium brasiliense (Greville) M.A. Howe \& W.R. Taylor (Gressler et al., 2011), Gracilaria domingensis (Kützing) Sonder ex Dickie, G. birdiae Plastino \& E.C. Oliveira, Laurencia dendroidea J. Agardh (as L. filiformis (C.Agardh) Montagne), and Laurencia sp. (as L. intricata J.V. Lamouroux) (Gressler et al., 2010), brown algae such as Sargassum aquifolium (Turner) C. Agardh (as S. binderi Sonder ex J. Agardh) and S. ilicifolium (Turner) C.Agardh (as S. duplicatum (J. Agardh) J. Agardh) (Noviendri et al., 2011) and green algae such as Ulva pertusa Kjellman (Floreto et al., 1993). It is important to note that the fatty acid profile of many organisms can vary according to environmental changes. For example, Floreto et al. (1993) observed an increase in the composition of saturated fatty acids and a decrease in unsaturated fatty acids of $U$. pertusa collected from mid-spring to early summer (March-June).

The results of the fatty acid profiles suggest that $S$. cymosum is the most suitable species to be used for biodiesel production, since biodiesel with a higher monounsaturated fatty acid content has a greater oxidative stability and does not precipitate when subjected to lower temperatures (Serdari et al. 1999). However, further studies of the growth of this species, as well as the yield, are needed to evaluate the economic viability of production of the compounds of interest.

\section{Acknowledgements}

This work was supported by FAPESP, CAPES, CNPq, Ministério da Saúde, Ministério de Ciência e Tecnologia, NAP-USP de Biodiversidade Marinha and CNPq-INCT-Redoxoma.

\section{References}

AOAC 2001, Official Method 996.06. Fat (total, saturated, and unsaturated) in foods. Hydrolytic extraction gas chromatography method (approved 1996, revised 2001).

Aresta M, Dibenedetto A, Carone M, Colonna T, Fragale C 2005. Production of biodiesel from macroalgae by supercritical $\mathrm{CO} 2$ extraction and thermochemical liquefaction. Environ Chem Lett 3: 136-139.

Bligh EG, Dyer WJ 1959. A rapid method of total lipid extraction and purification. Can J Biochem Physiol 37: 911-917.

Cardozo KHM, Guaratini T, Barros MP, Falcão VR, Tonon AP, Lopes NP, Campos S, Torres MA, Souza AO, Colepicolo P, Pinto E 2007. Metabolites from algae with economical impact. Comp Biochem Physiol 146: 60-78.

Cardozo KHM, Vessecchi R, Carvalho VM, Pinto E, Gates PJ, Colepicolo P, Galembeck SE, Lopes NP 2008. A theoretical and mass spectrometry study of the fragmentation of mycosporine-like amino acids. Int $J$ Mass Spectrom 273: 11-19.

Carrapiso AI, García C 2000. Development in lipid analysis: some new extraction techniques and in situ transesterification. Lipids 35: 1167-1177.

Cequier-Sànchez E, Rodriguez C, Ravelo AG, Zàrate R 2008. Dichloromethane as a solvent for lipid extraction and assessment of lipid classes and fatty acids from samples of different natures. J Agric Food Chem 56: 4297-4303.

Chisti Y 2007. Biodiesel from microalgae. Biotechnol Adv 25: 294-306.

Floreto EAT, Hirata H, Ando S, Yamasaki S 1993. Fatty acid composition of Ulva pertusa Kjellman (Chlorophyta) and Gracilaria incurvata Okamura (Rhodophyta) in Japanese coastal waters. Bot Mar 36: 217-222.

Folch J, Lees M, Sloane-Stanley GH 1957. A simple method for the isolation and purification of total lipids from animal tissues. J Biol Chem 226: 497-509.

Gressler V, Colepicolo P, Pinto E 2009. Useful strategies for algal volatile analysis. Current Anal Chem 5: 271292.

Gressler V, Yokoya NS, Fujii MT, Colepicolo P, ManciniFilho J, Torres RP, Pinto E 2010. Lipid, fatty acid, protein, amino acid and ash contents in four Brazilian red algae species. Food Chem 120: 585-590.

Gressler V, Fujii MT, Martins AP, Colepicolo P, ManciniFilho J, Pinto E 2011. Biochemical composition of two red seaweed species grown on the Brazilian coast. J Sci Food Agric 91: 1687-1692.

Guaratini T, Lopes NP, Pinto E, Colepicolo P, Gates P 2007. Differential ionisation of natural antioxidant polyenes in ESI and NanoESI mass spectrometry. Rapid Comm Mass Sp 21: 3842-3848.

Khotimchenko SV 1991. Fatty acid composition of seven Sargassum species. Phytochemistry 30: 2639-2641.

Kumari P, Reddy CRK, Jha B 2011. Comparative evaluation and selection of a method for lipid and fatty acid extraction from macroalgae. Anal Biochem 415: 134144.

Marchetti JM, Miguel VU, Errazu AF 2007. Possible methods for biodiesel production. Renew Sust Energy Rev 11: 1300-1311. 
Noviendri D, Jaswir I, Salleh HM, Taher M, Miyashita K, Ramli N 2011. Fucoxanthin extraction and fatty acid analysis of Sargassum binderi and S. duplicatum. $J$ Medic Plant Res 11: 2405-2412.

Ortiz J, Romero N, Robert P, Araya J, Lopez-Hernandez J, Bozzo C, Navarrete E, Osorio A, Rios A 2006. Dietary fiber, amino acid, fatty acid and tocopherol contents of the edible seaweeds Ulva lactuca and Durvillaea antarctica. Food Chem 99: 98-104.

Ramos MJ, Fernández CM, Casas A, Rodríguez L, Pérez Á 2009. Influence of fatty acid composition of raw materials on biodiesel properties. Biores Technol 100: 261-268.

Serdari A, Lois E, Stournas S 1999. Impact of esters of mono- and dicarboxilic acids on diesel fuel quality. Ind Eng Chem Res 38: 3543-3548.

Yaich H, Garna H, Besbes S, Paquot M, Blecker C, Attia H 2011. Chemical composition and functional properties of Ulva lactuca seaweed collected in Tunisia. Food Chem 128: 895-901.

\section{*Correspondence}

\section{Pio Colepicolo}

Departamento de Bioquímica, Instituto de Química, Universidade de São Paulo, Brazil,

piocolep@iq.usp.br

Tel. +55 1130919048 